\title{
FAKTOR-FAKTOR YANG BERHUBUNGAN DENGAN KEPUTUSAN PASIEN DALAM MEMILIH PELAYANAN RAWAT INAP
}

\author{
Heni Fa'riatul Aeni*, Yuniah Suwaryo**
}

\begin{abstract}
ABSTRAK
Menurut Anderson R (1968) dalam behavioral model of families use of health services, perilaku orang sakit berobat ke pelayanan kesehatan secara bersama-sama dipengaruhi oleh faktor predisposisi (usia, jenis kelamin, pendidikan, pekerjaan), faktor pemungkin (ekonomi keluarga, akses terhadap sarana pelayanan kesehatan yang ada dan penanggung biaya berobat) dan faktor kebutuhan (kondisi individu yang mencakup keluhan sakit). Penurunan utilisasi atau jumlah pasien rawat inap yang jika dibandingkan pada semester 1 tahun 2013 (bulan Januari 2013 sampai dengan Juni 2013) dengan semester 1 tahun 2012 (bulan Januari 2012 sampai dengan Juni 2012) menunjukan penurunan sebanyak $0,87 \%$. Penelitian ini bertujuan untuk mengetahui factor-faktor yang berhubungan dengan keputusan pasien rawat inap dalam memilih pelayanan rawat inap di RS Pertamina Cirebon tahun 2014. Jenis penelitian yang digunakan adalah penelitian kuantitatif dengan desain penelitian cross sectional dengan populasi penelitian adalah seluruh pasien rawat inap dalam satu bulan sebanyak 492, sedangkan jumlah sampel yang diambil sebanyak 100 dengan metode pengambilan non random sampling yang menggunakan teknik quota sampling. Hasil penelitian diperoleh bahwa faktor karakteristik pasien yang memiliki hubungan dengan keputusan pasien untuk memilih pelayanan rawat inap hanya karakteristik sosial pengaruh kelompok acuan, sedangkan faktor karakteristik pasien (pendidikan, pekerjaan, keadaan ekonomi, dan cara pembayaran), faktor sosial keluarga, faktor budaya tidak ada hubungan dengan keputusan untuk memilih pelayanan rawat inap. Faktor psikologi pasien yang memiliki hubungan dengan keputusan untuk memilih pelayanan rawat inap hanya persepsi terhadap bauran pemasaran SDM dan proses, sedangkan faktor lainnya seperti motivasi, pembelajaran, bauran produk, harga, tempat, promosi, dan bukti fisik tidak ada hubungan dengan keputusan untuk memilih pelayanan rawat inap di RS Pertamina Cirebon.
\end{abstract}

Kata Kunci : karakteristik pasien, psikologi, keputusan pasien

\begin{abstract}
According to Anderson R (1968) in behavioral models of families use of health services, the behavior of the sick medical treatment to the ministry of health jointly influenced by predisposing factor (age, gender, education, employment), enabling factor (economi families, access to the means of the existing health services and treatment costs of the insures), and the reinforcing factors (condition of the individual that includes complaints of pain). Utilization decline or in-patient number that when compared in semester of 1 years 2013 (January 2013 inclusive Juni 2013) with semsester of 1 years 2012 (January 2012 inclusive Juni 2012) shows declineas much $0,87 \%$. This research aimed to know factors that related to in-patient decision in selecting service in-patient in Rumah Sakit Pertamina Cirebon years 2014. Research used inquantitative with cross sectional with a population was all patients hospitalized in one month as much as 492, while the number of samples taken as many as 100 by the method of making non-random sampling using quota sampling technique. The results showed that the factor characteristics of patients who have a relationship with the patient's decision to choose inpatient services only social characteristics influence the reference group, while the factor of patient characteristics (education, employment, economic conditions, and method of payment), family social factors, cultural factors do not exist relationship with the decision to choose inpatient services. Psychological factors of patients who have a relationship with the decision to choose in patient only the perception of the marketing mix of human resources and processes, while other factors such as motivation, learning, product mix, price, place, promotion, and physical, evidence of no association with the decision to choose a service pertamina hospital patient in Cirebon. Keywords : patient characteristics, psychology, patient decision.
\end{abstract}

\footnotetext{
* Staf Pengajar Program Studi S1 Kesehatan Masyarakat STIKes Cirebon

** Alumni PSKM STIKes Cirebon Lulus Tahun 2014
} 


\section{PENDAHULUAN}

Berbagai upaya pelayanan kesehatan atau program kesehatan selalu bersinggungan dengan perilaku, hal ini disebabkan karena semua masalah kesehatan selalu mempunyai aspek perilaku sebagai faktor risiko. ${ }^{1}$ Menurut Widayatun (2009) manusia berperilaku atau beraktifitas karena adanya kebutuhan untuk mencapai suatu tujuan. Dengan adanya need atau kebutuhan dalam diri seseorang maka akan muncul motivasi atau penggerak. ${ }^{2}$ Menurut Anderson R (1968) dalam behavioral model of families use of health services, perilaku orang sakit berobat ke pelayanan kesehatan secara bersama-sama dipengaruhi oleh faktor predisposisi (usia, jenis kelamin, pendidikan, pekerjaan), faktor pemungkin (ekonomi keluarga, akses terhadap sarana pelayanan kesehatan yang ada dan penanggung biaya berobat) dan faktor kebutuhan (kondisi individu yang mencakup keluhan sakit). ${ }^{3}$

Menurut UU RI No.44 tahun 2009 rumah sakit adalah institusi kesehatan yang menyelenggarakan pelayanan kesehatan secara paripurna yang menyediakan pelayanan rawat inap, rawat jalan, dan gawat darurat. ${ }^{4}$ Dan sesuai dengan Kepmenkes RI No.129 tahun 2008 Rumah Sakit dituntut untuk memberikan pelayanan yang bermutu sesuai dengan standar yang ditetapkan dan dapat menjangkau seluruh lapisan masyarakat. ${ }^{5}$ Menurut Kementerian Kesehatan Republik Indonesia dalam Standart Pelayanan Rumah Sakit, mutu pelayanan merupakan kinerja yang merujuk pada tingkat kesempurnaan pelayanan kesehatan, yang disatu pihak dapat menimbulkan kepuasan pada setiap pasien sesuai dengan tingkat kepuasan rata-rata penduduk, serta dipihak lain tata cara penyelenggaraannya sesuai dengan standart dan kode etik profesi yang telah ditetapkan. ${ }^{5}$ Sehingga dapat dikatakan bahwa Rumah sakit sebagai penyedia jasa pelayanan kesehatan telah memberikan kualitas bila pelayanannya memenuhi atau melebihi harapan konsumen/pasiennya.

Hasil analisis kuesioner kepuasan pasien rawat inap di RS Pertamina semester 1 tahun 2012 (bulan Januari 2012 sampai dengan Juni 2012) prosentase pasien yang merasa tidak puas dengan pelayanan kesehatan di Rumah Sakit Pertamina Cirebon adalah 17,9\% dari total pasien yang mengisi kuesioner sebanyak 32.777 pasien. Sedangkan pada semester 1 tahun 2013 (bulan Januari 2013 sampai dengan Juni 2013) persentase pasien yang tidak puas dengan pelayanan kesehatan di Rumah Sakit Pertamina Cirebon adalah 18,6\% dari total pasien yang mengisi kuesioner sebanyak 40.660 pasien. ${ }^{6}$ Hasil Evaluasi tersebut jelas menunjukan peningkatan prosentase jumlah pasien yang tidak puas dengan pelayanan kesehatan di Rumah Sakit Pertamina Cirebon. Hasil tersebut mungkin saja berpengaruh terhadap penurunan utilisasi atau jumlah pasien rawat inap yang jika dibandingkan pada semester 1 tahun 2013 (bulan Januari 2013 sampai dengan Juni 2013) dengan semester 1 tahun 2012 (bulan Januari 2012 sampai dengan Juni 2012) menunjukan penurunan sebanyak $0,87 \% .^{7}$

Berdasarkan hasil kuesioner kepuasan pasien rawat inap di RS Pertamina Cirebon pada semester I tahun 2013, persentase pasien yang tidak puas terhadap pelayanan RS Pertamina Cirebon adalah 18,6\% dari total pasien yang mengisi kuesioner. Faktor-faktor ketidak puasan pasien tersebut diantaranya adalah faktor reliability (Kepercayaan terhadap layanan Dokter, Perawat \& Tenaga Penunjang) sebanyak 46\%, faktor tangible (Fasilitas Pelayanan) sebanyak $19 \%$, faktor responsiveness (respon petugas terhadap keluhan, kejelasan petugas memberikan keterangan, dan kesesuaian tarif pelayanan) sebanyak 16\%, faktor assurance (Ketrampilan, kemampuan, dan kesopanan petugas) sebanyak 11\%, faktor empati (Kesungguhan dan perhatian petugas dalam memberikan pelayanan) sebanyak $7 \% .^{7}$

Hasil uji statistik dalam penelitian tentang faktor-faktor yang berhubungan dengan niat untuk memilih pelayanan rawat inap di RS Bogor Medical Center tahun 2011 oleh RR.Nurmala Safitri, menunjukan bahwa terdapat hubungan yang bermakna antara faktor 
personal (pekerjaan), faktor sosial (keluarga dan kelompok acuan), faktor motivasi, faktor produk, faktor promosi, faktor sumber daya manusia, faktor bukti fisik dan faktor proses dengan niat untuk memilih pelayanan rawat inap di RS Bogor Medical Center. ${ }^{8}$

Penelitian ini bertujuan untuk mengetahui faktor-faktor apa saja yang berhubungan dengan keputusan pasien dalam memilih pelayanan rawat inap di RS Pertamina Cirebon dilihat dari segi karakteristik dan psikologi pasien rawat inap.

\section{METODE PENELITIAN}

Jenis penelitian yang digunakan adalah penelitian kuantitatif dengan desain penelitian cross sectional atau potong silang, dimana variabel independen (variabel yang mempengaruhi) yaitu karakteristik pasien (personal, sosial, dan budaya) dan psikologi pasien (motivasi, pembelajaran, dan persepsi pasien terhadap bauran pemasaran pelayanan) dan variabel dependen (variabel yang dipengaruhi) yaitu Keputusan pasien untuk memilih pelayanan rawat inap di RSPC diukur dan diamati pada waktu yang sama. ${ }^{9}$

Populasi penelitian adalan seluruh pasien rawat inap dalam satu bulan sebanyak 492, sedangkan jumlah sampel yang diambil sebanyak 100 dengan metode pengambilan non random sampling yang menggunakan teknik quota sampling.

\section{HASIL PENELITIAN}

\section{Karakteristik Pasien}

Tabel 1 Distribusi Data Kategorik Karakteristik Pasien Rawat Inap

\begin{tabular}{lccc}
\hline Variabel & Kategori & Frekuensi & Persentase (\%) \\
\hline Pendidikan & Tinggi & 51 & 51 \\
Pekerjaan & Rendah & 49 & 49 \\
& Bekerja & 72 & 72 \\
Keadaan Ekonomi & Tidak Bekerja & 28 & 28 \\
& Tinggi & 77 & 77 \\
Cara Pembayaran & Rendah & 23 & 23 \\
Keluarga & Pribadi & 49 & 49 \\
& Jaminan & 51 & 51 \\
Kelompok Sosial & Besar & 46 & 46 \\
& Kecil & 54 & 54 \\
Budaya & Besar & 50 & 50 \\
& Kecil & 50 & 50 \\
& Besar & 52 & 52 \\
\hline
\end{tabular}

Faktor Psikologi

Tabel 2 Distribusi Data Kategorik Faktor Psikologi Pasien Rawat Inap

\begin{tabular}{lccc}
\hline Variabel & Kategori & Frekuensi & Persentase (\%) \\
\hline Motivasi & Besar & 46 & 46 \\
& Kecil & 54 & 54 \\
Pembelajaran & Besar & 59 & 59 \\
\multirow{2}{*}{ Produk } & Kecil & 41 & 41 \\
& Baik & 52 & 52 \\
Harga & Kurang Baik & 48 & 48 \\
& Baik & 38 & 38 \\
& Kurang Baik & 62 & 62 \\
\hline
\end{tabular}




\section{Faktor Psikologi}

Tabel 2 Distribusi Data Kategorik Faktor Psikologi Pasien Rawat Inap (Lanjutan)

\begin{tabular}{lccc}
\hline Variabel & Kategori & Frekuensi & Persentase (\%) \\
& & & \\
\hline Motivasi & Besar & 46 & 46 \\
& Kecil & 54 & 54 \\
Pembelajaran & Besar & 59 & 59 \\
Produk & Kecil & 41 & 41 \\
& Baik & 52 & 52 \\
Harga & Kurang Baik & 48 & 48 \\
& Baik & 38 & 38 \\
Tempat & Kurang Baik & 62 & 62 \\
& Baik & 52 & 52 \\
Promosi & Kurang Baik & 48 & 48 \\
\multirow{2}{*}{ SDM } & Baik & 49 & 49 \\
& Kurang Baik & 51 & 51 \\
Bukti Fisik & Baik & 48 & 48 \\
& Kurang Baik & 52 & 52 \\
Proses & Baik & 47 & 47 \\
& Kurang Baik & 53 & 53 \\
\hline
\end{tabular}

\section{Keputusan Pasien}

Tabel 3 Distribusi Data Kategorik Keputusan Pasien Rawat Inap

\begin{tabular}{lccc}
\hline Variabel & Kategori & Frekuensi & Presentase (\%) \\
\hline Keputusan untuk memilih & Tidak Memilih & 28 & 28 \\
& Memilih & 72 & 72
\end{tabular}

Hubungan Antara Karakteristik Pasien dengan Keputusan untuk Memilih Pelayanan Rawat Inap

\begin{tabular}{|c|c|c|c|c|c|c|c|c|}
\hline \multirow{2}{*}{\multicolumn{2}{|c|}{ Nama Variabel }} & \multirow[t]{2}{*}{ Kategori } & \multicolumn{2}{|c|}{$\begin{array}{c}\text { Tidak } \\
\text { memilih }\end{array}$} & \multicolumn{2}{|c|}{ Memilih } & \multirow[t]{2}{*}{ P Value } & \multirow[t]{2}{*}{$95 \% \mathrm{CI}$} \\
\hline & & & $N$ & $\%$ & $N$ & $\%$ & & \\
\hline \multirow{3}{*}{\multicolumn{2}{|c|}{$\begin{array}{l}\text { 1. Personal } \\
\text { - Pendidikan }\end{array}$}} & & & & & & & \\
\hline & & Rendah & 12 & 26 & 37 & 37 & 0,587 & $1,39-1,59$ \\
\hline & & Tinggi & 16 & 62 & 35 & 35 & & \\
\hline \multirow{3}{*}{\multicolumn{2}{|c|}{ - Pekerjaan }} & Tidak & 6 & 6 & 22 & 22 & 0,506 & $1,19-1,37$ \\
\hline & & Bekerja & & & & & & \\
\hline & & Bekerja & 22 & 22 & 50 & 50 & & \\
\hline & - Keadaan & Rendah & 6 & 6 & 17 & 17 & 1,000 & $1,15-1,31$ \\
\hline & Ekonomi & Tinggi & 22 & 22 & 55 & 55 & & \\
\hline & - Cara & Pribadi & 12 & 12 & 37 & 37 & 0,587 & $1,41-1,61$ \\
\hline & Pembayaran & Jaminan & 16 & 16 & 35 & 35 & & \\
\hline \multicolumn{9}{|c|}{ 2. Sosial } \\
\hline \multirow{2}{*}{\multicolumn{2}{|c|}{ - Keluarga }} & Kecil & 19 & 19 & 35 & 35 & 0,131 & $4,54-5,64$ \\
\hline & & Besar & 9 & 9 & 37 & 37 & & \\
\hline \multirow{2}{*}{\multicolumn{2}{|c|}{$\begin{array}{l}\text { - Kelompok } \\
\text { acuan }\end{array}$}} & Kecil & 19 & 19 & 31 & 31 & 0,045 & $4,31-5,47$ \\
\hline & & Besar 1 & 9 & 9 & 41 & 41 & & \\
\hline \multirow{2}{*}{\multicolumn{2}{|c|}{ 3. Budaya }} & Kecil & 18 & 18 & 30 & 30 & 0,070 & $7,53-8,89$ \\
\hline & & Besar & 10 & 10 & 42 & 42 & & \\
\hline
\end{tabular}


Hubungan Antara Faktor Psikologi Pasien dengan Keputusan untuk Memilih Pelayanan Rawat Inap

\begin{tabular}{llllllll}
\hline Nama Variabel & Kategori & \multicolumn{2}{c}{ Tidak } & \multicolumn{2}{c}{ Memilih } & P Value & $95 \%$ CI \\
& & $N$ & $\%$ & $n$ & $\%$ & & \\
\hline 1. Motivasi & Rendah & 17 & 17 & 37 & 37 & 0,537 & $13,77-14,55$ \\
& Tinggi & 11 & 11 & 35 & 35 & & \\
2. Pembelajaran & Kecil & 13 & 13 & 28 & 28 & 0,644 & $10,7-11,32$ \\
& Besar & 15 & 15 & 44 & 44 & & \\
3. Bauran & & & & & & & \\
Pemasaran & & & & & & & \\
Jasa & & & & & & & \\
- Produk & Kurang baik & 17 & 17 & 31 & 31 & 0,173 & $13,85-14,63$ \\
& Baik & 11 & 11 & 41 & 41 & & \\
- Harga & Kurang baik & 14 & 14 & 48 & 48 & 0,189 & $12,83-13,65$ \\
& Baik & 14 & 14 & 24 & 24 & & \\
- Tempat & Kurang baik & 14 & 14 & 34 & 34 & 0,979 & $13,31-14,63$ \\
& Baik & 14 & 14 & 38 & 38 & & \\
- Promosi & Kurang baik & 19 & 19 & 32 & 32 & 0,060 & $7,17-8,03$ \\
& Baik & 9 & 9 & 40 & 40 & & \\
- SDM & Kurang baik & 23 & 23 & 29 & 29 & 0,000 & $13,76-14,48$ \\
& Baik & 5 & 5 & 43 & 43 & & \\
- Bukti Fisik & Kurang baik & 12 & 12 & 41 & 41 & 0,296 & $16,81-17,69$ \\
& Baik & 16 & 16 & 31 & 31 & & \\
- Proses & Kurang baik & 25 & 25 & 41 & 41 & 0,005 & $16,13-17,21$ \\
& Baik & 3 & 3 & 31 & 31 & & \\
\hline
\end{tabular}

\section{PEMBAHASAN}

\section{Karakteristik Pasien \\ Pendidikan}

Hasil penelitian yang menunjukan sebagian besar pasien memiliki tingkat pendidikan yang tinggi ini kemudian dapat digunakan sebagai salah satu acuan dalam merancang produk pelayanan, penggunaan strategi komunikasi untuk promosi, atau berbagai aktivitas pemasaran lain dalam rumah sakit ini.

Tiap orang memiliki gambaran diri yang kompleks, dan perilaku seseorang cenderung konsisten dengan konsep diri tersebut. ${ }^{10}$ Dan salah satu yang mungkin mempengaruhi konsep diri tersebut adalah tingkat pendidikan.

Namun berdasarkan uji chi square disimpulkan bahwa tidak ada hubungan yang signifikan antara faktor pendidikan pasien dengan keputusan untuk memilih pelayanan rawat inap di RS Pertamina Cirebon ( $p$ value 0,587 >0,05). Hasil tersebut sesuai dengan penelitian yang dilakukan sebelumnya oleh RR. Nurmala Safitri, tentang faktor-faktor yang berhubungan dengan niat untuk memilih pelayanan rawat inap di RS Bogor Medical Center tahun 2011.

Hal tersebut kemungkinan disebabkan RS Pertamina masih dianggap sebagai leader pelayanan kesehatan bagi sebagian besar masyarakat, sehingga tingkat pendidikan tidak berpengaruh dalam memilih pelayanan kesehatan. hal itu juga terlihat dari keberagaman tingkat pendidikan pasien dari yang paling rendah sampai yang paling tinggi.

\section{Pekerjaan}

Hasil penelitian ini menunjukan bahwa sebagian besar pasien adalah pegawai swasta/BUMN yaitu 29 orang(29\%), kemudian ibu rumah tangga sebanyak 20 orang (20\%), 
dan seterusnya. Hasil penelitian tersebut menunjukan bahwa karakteristik pasien di rumah sakit ini jika dilihat dari faktor pekerjaannya sebagian besar adalah bekerja.

Pekerjaan juga mempengaruhi pola konsumsi. ${ }^{10}$ Karena itu hasil penelitian ini kemudian dapat digunakan sebagai salah satu acuan dalam merancang produk pelayanan, penggunaan strategi komunikasi untuk promosi, atau berbagai aktivitas pemasaran lain dalam rumah sakit ini disesuaikan dengan minat konsumen berdasarkan jenis pekerjaannya.

Berdasarkan uji chi square disimpulkan bahwa tidak ada hubungan yang signifikan antara faktor pekerjaan pasien dengan keputusan untuk memilih pelayanan rawat inap di RS Pertamina Cirebon ( $p$ value $0,506>0,05$ ). Hasil tersebut tidak sesuai dengan penelitian yang dilakukan sebelumnya oleh RR. Nurmala Safitri, tentang faktor-faktor yang berhubungan dengan niat untuk memilih pelayanan rawat inap di RS Bogor Medical Center tahun 2011, yang menyatakan bahwa terdapat hubungan antara faktor personal pekerjaan dengan niat untuk memilih pelayanan rawat inap di RS Bogor Medical Center.

Hal tersebut kemungkinan dikarenakan sebagian pasien juga sebagai ibu rumah tangga, pelajar/mahasiswa yang pembiayaannya ditanggung oleh kepala keluarga, sehingga status pekerjaan juga tidak berpengaruh dalam memilih pelayanan kesehatan.

\section{Keadaan Ekonomi}

Berdasarkan hasil penelitian yang dilakukan dengan menyebarkan kuesioner kepada pasien rawat inap RS Pertamina Cirebon, diketahui bahwa sebagian besar pasien memiliki kedaan ekonomi tinggi yaitu sebesar 77 orang (77\%), dan sisanya memiliki keadaan ekonomi rendah sebanyak 23 orang $(23 \%)$.

Kotler, Amstrong berpendapat bahwa keadaan ekonomi seseorang akan mempengaruhi pilihan produk. Situasi ekonomi seseorang amat sangat mempengaruhi pemilihan produk dan keputusan pembelian pada suatu produk tertentu. ${ }^{11}$

Namun berdasarkan uji chi square disimpulkan bahwa tidak ada hubungan yang signifikan antara faktor keadaan ekonomi pasien dengan keputusan untuk memilih pelayanan rawat inap di RS Pertamina Cirebon ( $p$ value 1,00>0,05). Hasil tersebut sesuai dengan penelitian yang dilakukan sebelumnya oleh RR. Nurmala Safitri, tentang faktor-faktor yang berhubungan dengan niat untuk memilih pelayanan rawat inap di RS Bogor Medical Center tahun 2011.

Hal tersebut kemungkinan disebabkan keberagaman status dan jenis pekerjaan pasien, yang beberapa juga merupakan ibu rumah tangga, pelajar/mahasiswa, serta pensiunan beberapa perusahaan seperti PT.Pertamina, PT. Telkom, dan lain-lain yang memang jika dilihat dari segi penghasilan/keadaan ekonomi tidak mempengaruhi mereka untuk memilih RS Pertamina Cirebon, dikarenakan memang sistem penjaminan kesehatan yang mereka dapatkan adalah di rumah sakit ini.

\section{Cara Pembayaran}

Berdasarkan hasil penelitian sebagian besar pasien membayar dengan Jaminan perusahaan/asuransi yaitu sebesar 51 orang $(51 \%)$, sedangkan yang membayar dengan cara pribadi sebanyak 49 orang (49\%).

Kotler, Amstrong berpendapat bahwa keadaan ekonomi seseorang akan mempengaruhi pilihan produk. Situasi ekonomi seseorang amat sangat mempengaruhi pemilihan produk dan keputusan pembelian pada suatu produk tertentu. ${ }^{11}$ Cara pembayaran pengobatan erat kaitannya dengan situasi ekonomi.

Namun berdasarkan uji chi square disimpulkan bahwa tidak ada hubungan yang signifikan antara faktor cara pembayaran pasien dengan keputusan untuk memilih pelayanan rawat inap di RS Pertamina Cirebon ( $p$ value 0,587 > 0,05). Hasil tersebut sesuai dengan 
penelitian yang dilakukan sebelumnya oleh RR. Nurmala Safitri, tentang faktor-faktor yang berhubungan dengan niat untuk memilih pelayanan rawat inap di RS Bogor Medical Center tahun 2011.

Hal tersebut kemungkinan disebabkan masih banyaknya masyarakat yang percaya terhadap pelayanan kesehatan di RS Pertamina tanpa mempertimbangkan mereka akan membayar pribadi atau dengan jaminan perusahaan, hal tersebut juga terlihat dari prosentase antara pasien yang membayar dengan pribadi dengan pasien yang membayar dengan jaminan juga hampir seimbang.

\section{Sosial}

\section{Keluarga}

Berdasarkan hasil penelitian diketahui bahwa sebagian besar pasien termasuk kedalam kelompok dengan pengaruh keluarga yang memiliki nilai kecil yaitu sebanyak 54 orang (54\%) dan sisanya masuk ke dalam kelompok nilai besar yaitu 46 orang (46\%). Hal ini berarti sebagian besar pasien menganggap faktor keluarga tidak terlalu mempengaruhi mereka untuk memilih pelayanan kesehatan, termasuk dalam memilih rumah sakit saat mereka memerlukan pelayanan rawat inap.

Hal ini diperkuat dengan hasil uji chi square yaitu bahwa tidak ada hubungan yang signifikan antara faktor sosial keluarga pasien dengan keputusan untuk memilih pelayanan rawat inap di RS Pertamina Cirebon ( $p$ value $0,131>0,05$ ). Hasil tersebut tidak sesuai dengan penelitian yang dilakukan sebelumnya oleh RR. Nurmala Safitri, tentang faktor-faktor yang berhubungan dengan niat untuk memilih pelayanan rawat inap di RS Bogor Medical Center tahun 2011, yang menyatakan bahwa terdapat hubungan antara faktor sosial pengaruh keluarga dengan niat untuk memilih pelayanan rawat inap di RS Bogor Medical Center.

Hal ini kemungkinan disebabkan sebagian pasien menganggap ada faktor lain yang lebih kuat mempengaruhi selain keluarga, misalnya kepercayaan terhadap tenaga medis, kelengkapan pelayanan, dan lain-lain.

\section{Kelompok Acuan}

Pengertian kelompok acuan dalam penelitian ini yaitu kelompok lain selain keluarga. Kelompok acuan (teman, tetangga, rekan kerja) juga dianggap memiliki pengaruh terhadap keputusan pasien dalam memilih pelayanan kesehatan, pengaruh tersebut dapat berupa rekomendasi, eksekutor (pengambil keputusan, dan sebagainya.

Berdasarkan hasil penelitian di RS Pertamina Cirebon diketahui bahwa kelompok dengan pengaruh kelompok acuan yang memiliki nilai kecil sama banyak dengan kelompok nilai besar yaitu masing-masing 50 orang (50\%). Hal ini berarti seimbang antara jumlah pasien yang menganggap faktor kelompok acuan berpengaruh dan tidak terlalu mempengaruhi mereka untuk memilih pelayanan kesehatan, termasuk dalam memilih rumah sakit saat mereka memerlukan pelayanan rawat inap. Hal ini diperkuat dengan hasil uji chi square yaitu bahwa terdapat hubungan yang signifikan antara faktor sosial kelompok acuan pasien dengan keputusan untuk memilih pelayanan rawat inap di RS Pertamina Cirebon ( $p$ value $0,045<$ 0,05). Hasil tersebut juga sesuai dengan penelitian yang dilakukan sebelumnya oleh RR. Nurmala Safitri, tentang faktor-faktor yang berhubungan dengan niat untuk memilih pelayanan rawat inap di RS Bogor Medical Center tahun 2011.

Hal tersebut kemungkinan disebabkan banyaknya pasien yang mendapat rekomendasi dari rekan kerja, tetangga, teman/sahabat, maupun rujukan dari dokter pribadi atau tenaga kesehatan lain diwilayah tempat tinggalnya. 


\section{Budaya}

Menurut Kotler, Amstrong Kebudayaan adalah nilai-nilai dasar, persepsi, keinginan, dan perilaku yang dipelajari seseorang melalui keluarga dan lembaga penting lainnya. Penentu paling dasar dari keinginan dan perilaku seseorang. ${ }^{11}$ Sedangkan Kotler, Bowen, Makens menjelaskan bahwa culture mengkompromikan nilai-nilai dasar, persepsi, keinginan, dan perilaku yang dipelajari seseorang secara terus-menerus dalam sebuah lingkungan. ${ }^{12}$

Berdasarkan hasil penelitian yang dilakukan dengan menyebarkan kuesioner kepada pasien rawat inap di RS Pertamina Cirebon diketahui bahwa sebagian besar pasien termasuk kedalam kelompok dengan pengaruh budaya yang memiliki nilai besar yaitu sebanyak 52 orang $(52 \%)$ dan sisanya masuk ke dalam kelompok nilai kecil yaitu 48 orang (48\%). Hal ini berarti ada sebagian besar pasien yang menganggap faktor budaya mempengaruhi mereka untuk memilih pelayanan kesehatan, termasuk dalam memilih rumah sakit saat mereka memerlukan pelayanan rawat inap.

Namun hasil uji chi square menunjukan bahwa tidak ada hubungan yang signifikan antara faktor budaya dengan keputusan untuk memilih pelayanan rawat inap di RS Pertamina Cirebon ( $p$ value $0,070>0,05$ ). Hasil tersebut juga sesuai dengan penelitian yang dilakukan sebelumnya oleh RR. Nurmala Safitri, tentang faktor-faktor yang berhubungan dengan niat untuk memilih pelayanan rawat inap di RS Bogor Medical Center tahun 2011. Hal tersebut kemungkinan disebabkan besarnya pengaruh budaya dianggap oleh pasien bukan menjadi alasan utama mereka memilih RS Pertamina Cirebon, tetapi ada faktor lain yang lebih mempengaruhi.

\section{Psikologi Pasien \\ Motivasi}

Kebutuhan yang mendesak untuk mengarahkan seseorang untuk mencari kepuasan dari kebutuhan. Berdasarkan teori Maslow, seseorang dikendalikan oleh suatu kebutuhan pada suatu waktu. Kebutuhan manusia diatur menurut sebuah hierarki, dari yang paling mendesak sampai paling tidak mendesak (kebutuhan psikologikal, keamanan, sosial, harga diri, pengaktualisasian diri). Ketika kebutuhan yang paling mendesak itu sudah terpuaskan, kebutuhan tersebut berhenti menjadi motivator, dan orang tersebut akan kemudian mencoba untuk memuaskan kebutuhan paling penting berikutnya. ${ }^{13}$

Berdasarkan hasil penelitian bahwa sebagian besar pasien di Rumah Sakit Pertamina Cirebon termasuk kedalam kelompok yang memiliki nilai motivasi kecil yaitu sebanyak 54 orang (54\%) dan sisanya masuk ke dalam kelompok nilai besar yaitu 46 orang (46\%).

Hasil uji chi square menunjukan bahwa tidak ada hubungan yang signifikan antara faktor motivasi dengan keputusan untuk memilih pelayanan rawat inap di RS Pertamina Cirebon ( $p$ value $0,537>0,05)$. Hasil tersebut tidak sesuai dengan penelitian yang dilakukan sebelumnya oleh RR. Nurmala Safitri, tentang faktor-faktor yang berhubungan dengan niat untuk memilih pelayanan rawat inap di RS Bogor Medical Center tahun 2011, yang menyatakan bahwa terdapat hubungan antara faktor motivasi dengan niat untuk memilih pelayanan rawat inap di RS Bogor Medical Center.

Hal ini kemungkinan disebabkan karena motif rasional yang di ukur melalui kepuasan pasien dan motif emosional yang diukur melalui perasaan nyaman atau suka terhadap pelayanan kesehatan di RS Pertamina Cirebon menunjukan hasil yang kurang baik dan hal itu juga kurang mempengaruhi pasien dalam memilih pelayanan kesehatan rawat inap. 


\section{Pembelajaran}

Pada penelitian ini peneliti menggunakan teori pembelajaran yang lebih aktif yaitu meneliti tentang respon pasien terhadap pembelajaran negatif yang dialami atau diketahui oleh pasien selama mendapatkan pelayanan di RS Pertamina Cirebon. Berdasarkan teori bias hedonis, orang memiliki kecenderungan umum untuk mengaitkan keberhasilan dan kegagalan diri mereka pada penyebab eksternal. ${ }^{10}$ Untuk itu jika pasien mendapatkan atau mengetahui pengalaman yang negatif selama mendapatkan pelayanan di rumah sakit ini, pasien tersebut akan cenderung menyalahkan produk atau pelayanan yang ada. Hal ini tentu akan berpengaruh terhadap perilaku pasien selanjutnya, termasuk dalam memilih pelayanan rawat inap jika suatu hari ia memerlukan pelayanan rawat inap lagi.

Berdasarkan hasil penelitian diketahui bahwa hanya sebagian kecil pasien di Rumah Sakit Pertamina Cirebon yang mendapatkan dan atau mengetahui pembelajaran negatif selama mendapatkan pelayanan di RS Pertamina Cirebon yaitu sebanyak 41 orang (41\%). Sedangkan sebanyak 59 pasien menganggap bahwa mereka tidak pernah mengalami atau mengetahui adanya pembelajaran negatif .

Hasil uji chi square menunjukan bahwa tidak ada hubungan yang signifikan antara faktor pembelajaran dengan keputusan untuk memilih pelayanan rawat inap di RS Pertamina Cirebon ( $p$ value $0,644>0,05$ ). Hasil tersebut juga sesuai dengan penelitian yang dilakukan sebelumnya oleh RR. Nurmala Safitri, tentang faktor-faktor yang berhubungan dengan niat untuk memilih pelayanan rawat inap di RS Bogor Medical Center tahun 2011.

Hal ini kemungkinan disebabkan respon pasien terhadap pembelajaran negatif yang dialami atau diketahui oleh pasien selama mendapatkan pelayanan di RS Pertamina Cirebon tidak berpengaruh terhadap keputusan pasien, dan pasien memiliki alasan yang lebih kuat untuk memilih atau tidak memilih pelayanan kesehatan di RS Pertamina Cirebon, misalnya faktor tenaga medis, kelengkapan alat, dan lain-lain.

\section{Persepsi Pasien Terhadap Bauran Pemasaran Pelayanan Produk}

Berdasarkan penelitian mengenai gambaran persepsi pasien di Rumah Sakit Pertamina Cirebon terhadap bauran pemasaran produk diketahui bahwa sebagian besar persepsi pasien temasuk kedalam kelompok baik yaitu sebanyak 52 orang (52\%) dan sisanya masuk kedalam kelompok nilai kurang baik sebanyak 48 orang (48\%). Adapun komponen yang dinilai dalam penelitian ini yaitu mengenai kelengkapan dan kualitas produk pelayanan/jasa di rumah sakit ini.

Hasil penelitian ini menggambarkan adanya kepuasan pasien yaitu kesesuaian antara kualitas yang diberikan oleh rumah sakit sebagai penyedia jasa dengan apa yang dibutuhkan pasien sebagai penerima jasa.

Dalam teori "model perilaku konsumen" disebutkan bahwa produk merupakan salah satu unsur dari bauran pemasaran yang memberikan stimuli atau rangsangan kepada konsumen dalam proses pengambilan keputusan pembelian. ${ }^{10} \mathrm{Namun}$ berdasarkan hasil uji chi square disimpulkan bahwa tidak ada hubungan atau pengaruh yang signifikan antara persepsi pasien terhadap bauran pemasaran produk dengan keputusan untuk memilih pelayanan rawat inap di RS Pertamina Cirebon $(P$ value $0,173>0,05)$. Hasil tersebut tidak sesuai dengan penelitian yang dilakukan sebelumnya oleh RR. Nurmala Safitri, tentang faktor-faktor yang berhubungan dengan niat untuk memilih pelayanan rawat inap di RS Bogor Medical Center tahun 2011, yang menyatakan bahwa terdapat hubungan antara faktor produk dengan niat untuk memilih pelayanan rawat inap di RS Bogor Medical Center. 
Hal tersebut kemungkinan disebabkan pasien menganggap RS Pertamina bukan satu-satunya rumah sakit di wilayah cirebon yang memiliki kelengkapan fasilitas pelayanan.

\section{Harga}

Harga adalah salah satu elemen bauran pemasaran yang menghasilkan pendapatan. Harga mungkin merupakan elemen termudah untuk disesuaikan dalam program pemasaran. Elemen produk, saluran, bahkan promosi membutuhkan lenih banyak waktu. Harga juga mengkomunikasikan positioning nilai dari produk/jasa atau merek produsen ke pasar. Produk/jasa yang dirancang dan dipasarkan dengan baik dapat dijual dengan harga tinggi dan menghasilkan laba yang besar. ${ }^{10}$

Berdasarkan penelitian mengenai gambaran persepsi pasien terhadap bauran pemasaran harga diketahui bahwa sebagian besar persepsi pasien temasuk kedalam kelompok kurang baik yaitu sebanyak 62 orang $(62 \%)$ dan sisanya masuk kedalam kelompok nilai baik sebanyak 38 orang $(38 \%)$. Adapun komponen yang dinilai dalam penelitian ini yaitu mencakup harga pelayanan yang terjangkau, kesesuaian harga dengan pelayanan, respon pasien bila harga dinaikkan, dan pengaruh harga tersebut terhadap keputusan untuk memilih pelayanan rawat inap di RS Pertamina Cirebon.

Berdasarkan hasil uji chi square disimpulkan bahwa tidak ada hubungan atau pengaruh yang signifikan antara persepsi pasien terhadap bauran pemasaran harga dengan keputusan untuk memilih pelayanan rawat inap di RS Pertamina Cirebon $(P$ value $0,189>0,05)$. Hasil tersebut juga sesuai dengan penelitian yang dilakukan sebelumnya oleh RR. Nurmala Safitri, tentang faktor-faktor yang berhubungan dengan niat untuk memilih pelayanan rawat inap di RS Bogor Medical Center tahun 2011. Namun hasil uji ini tidak sesuai dengan teori mengenai perilaku konsumen yang dikemukakan oleh Kotler dan Keller yang menyatakan proses keputusan pembelian dipengaruhi oleh rangsangan pemasaran yang salah satunya merupakan faktor harga. ${ }^{10}$

Hal tersebut kemungkinan disebabkan bahwa persepsi pasien yang kurang baik terhadap harga tidak menjadi alasan utama mereka untuk memilih atau tidak memilih pelayanan kesehatan di RS Pertamina, hal tersebut juga dilihat dari sebagian besar pasien adalah bekerja dengan keadaan ekonomi yang tinggi.

\section{Tempat}

Berdasarkan penelitian mengenai gambaran persepsi pasien terhadap bauran pemasaran tempat diketahui bahwa sebagian besar persepsi pasien temasuk kedalam kelompok baik yaitu sebanyak 52 orang (52\%) dan sisanya masuk kedalam kelompok nilai kurang baik sebanyak 48 orang (48\%). Adapun komponen yang dinilai dalam penelitian ini yaitu mencakup lokasi yang strategis, kemudahan dijangkau dengan transportasi pribadi maupun transportasi umum, lokasi yang dekat dengan tempat tinggal, dan pengaruhnya terhadap keputusan untuk memilih pelayanan rawat inap di RS Pertamina Cirebon.

Berdasarkan hasil uji chi square disimpulkan bahwa tidak ada hubungan atau pengaruh yang signifikan antara persepsi pasien terhadap bauran pemasaran tempat dengan keputusan untuk memilih pelayanan rawat inap di RS Pertamina Cirebon $(P$ value $0,979>0,05)$. Hasil tersebut juga sesuai dengan penelitian yang dilakukan sebelumnya oleh RR. Nurmala Safitri, tentang faktor-faktor yang berhubungan dengan niat untuk memilih pelayanan rawat inap di RS Bogor Medical Center tahun 2011. Namun hasil uji ini tidak sesuai dengan teori mengenai perilaku konsumen yang dikemukakan oleh Kotler dan Keller yang menyatakan proses keputusan pembelian dipengaruhi oleh rangsangan pemasaran yang salah satunya merupakan faktor tempat. ${ }^{10} \mathrm{Hal}$ ini kemungkinan disebabkan sebagian besar pasien RS Pertamina Cirebon 
berasal dari Kabupaten Indramayu yang jika dilihat dari segi jarak adalah jauh, dan hal tersebut tidak menghalangi mereka untuk memilih pelayanan kesehatan di RS Pertamina Cirebon.

\section{Promosi}

Berdasarkan penelitian mengenai gambaran persepsi pasien terhadap bauran pemasaran promosi diketahui bahwa sebagian besar persepsi pasien temasuk kedalam kelompok kurang baik yaitu sebanyak 51 orang $(51 \%)$ dan sisanya masuk kedalam kelompok nilai baik sebanyak 49 orang (49\%). Adapun komponen yang dinilai dalam penelitian ini yaitu mencakup pernah atau tidaknya pasien mengetahui promosi yang dilakukan oleh rumah sakit, kemudahan mendapatkan informasi mengenai pelayanan rumah sakit, dan kelengkapan informasi tersebut, dan pengaruhnya terhadap keputusan untuk memilih pelayanan rawat inap di RS Pertamina Cirebon.

Berdasarkan hasil uji chi square disimpulkan bahwa tidak ada hubungan atau pengaruh yang signifikan antara persepsi pasien terhadap bauran pemasaran promosi dengan keputusan untuk memilih pelayanan rawat inap di RS Pertamina Cirebon $(P$ value $0,06>0,05)$. Hasil tersebut tidak sesuai dengan penelitian yang dilakukan sebelumnya oleh RR. Nurmala Safitri, tentang faktor-faktor yang berhubungan dengan niat untuk memilih pelayanan rawat inap di RS Bogor Medical Center tahun 2011, yang menyatakan bahwa terdapat hubungan antara faktor promosi dengan niat untuk memilih pelayanan rawat inap di RS Bogor Medical Center.

Hasil uji ini juga tidak sesuai dengan teori mengenai perilaku konsumen yang dikemukakan oleh Kotler dan Keller yang menyatakan proses keputusan pembelian dipengaruhi oleh rangsangan pemasaran yang salah satunya merupakan faktor promosi. ${ }^{10}$ Hasil penelitian ini kemungkinan disebabkan masih kurangnya upaya RS Pertamina Cirebon dalam melakukan komunikasi dan memberikan informasi kepada konsumen. Namun hal tersebut juga dapat disebabkan karena rumah sakit merupakan institusi sosial yang memiliki keterbatasan dalam melakukan upaya promosi.

\section{Sumber Daya Manusia (SDM)}

Sumber daya manusia dalam pemasaran jasa merupakan semua aktor manusia yang berperan dalam penyediaan pelayanan yang mempengaruhi persepsi konsumen, yaitu personil penyedia pelayanan, pelanggan, dan pelanggan lain dalam lingkungan pelayanan. ${ }^{14} \mathrm{SDM}$ berfungsi sebagai penyedia jasa yang sangat mempengaruhi kualitas jasa yang diberikan.

Hasil penelitian mengenai gambaran persepsi pasien terhadap bauran pemasaran SDM diketahui bahwa sebagian besar persepsi pasien temasuk kedalam kelompok kurang baik yaitu sebanyak 52 orang (52\%) dan sisanya masuk kedalam kelompok nilai baik sebanyak 48 orang (48\%). Adapun komponen yang dinilai dalam penelitian ini yaitu mengenai kemampuan/kompetensi SDM tersebut, profesionalisme, dan keramahannya terhadap konsumen, serta pengaruhnya terhadap keputusan untuk memilih pelayanan rawat inap di RS Pertamina Cirebon.

Hasil uji chi square menunjukkan bahwa ada hubungan atau pengaruh yang signifikan antara persepsi pasien terhadap bauran pemasaran SDM dengan keputusan untuk memilih pelayanan rawat inap di RS Pertamina Cirebon $(P$ value $0,00<0,05)$. Hasil tersebut juga sesuai dengan penelitian yang dilakukan sebelumnya oleh RR. Nurmala Safitri, tentang faktor-faktor yang berhubungan dengan niat untuk memilih pelayanan rawat inap di RS Bogor Medical Center tahun 2011. Hasil uji ini juga sesuai dengan teori mengenai perilaku konsumen yang dikemukakan oleh Kotler dan Keller yang menyatakan proses keputusan pembelian dipengaruhi oleh bauran pemasaran yang salah satunya merupakan faktor 
SDM. ${ }^{10}$ Hasil penelitian ini kemungkinan menunjukan persepsi pasien terhadap kualitas SDM rumah sakit menjadi salah satu alasan utama pasien memilih RS Pertamina Cirebon, yang kemungkinan besar adalah dokter-dokter spesialis nya yang lengkap dari berbagai bidang, serta perawat-perawatnya yang profesional dan dikenal ramah.

\section{Bukti Fisik}

Hasil penelitian mengenai gambaran persepsi pasien terhadap bauran pemasaran bukti fisik diketahui bahwa sebagian besar persepsi pasien temasuk kedalam kelompok kurang baik yaitu sebanyak 53 orang (53\%) dan sisanya masuk kedalam kelompok nilai baik sebanyak 47 orang $(47 \%)$. Adapun komponen yang dinilai dalam penelitian ini yaitu mencakup gedung dan fasilitas, desain dan tata letak, peralatam kebersihan, dan pengaruhnya terhadap keputusan untuk memilih pelayanan rawat inap di RS Pertamina Cirebon.

Berdasarkan hasil uji chi square disimpulkan bahwa tidak ada hubungan atau pengaruh yang signifikan antara persepsi pasien terhadap bauran pemasaran bukti fisik dengan keputusan untuk memilih pelayanan rawat inap di RS Pertamina Cirebon $(P$ value 0,296 > 0,05). Hasil tersebut tidak sesuai dengan penelitian yang dilakukan sebelumnya oleh RR. Nurmala Safitri, tentang faktor-faktor yang berhubungan dengan niat untuk memilih pelayanan rawat inap di RS Bogor Medical Center tahun 2011, yang menyatakan bahwa terdapat hubungan antara faktor bukti fisik dengan niat untuk memilih pelayanan rawat inap di RS Bogor Medical Center.

Hasil uji ini juga tidak sesuai dengan teori mengenai perilaku konsumen yang dikemukakan oleh Kotler dan Keller yang menyatakan proses keputusan pembelian dipengaruhi oleh rangsangan pemasaran yang salah satunya merupakan faktor bukti fisik. Hal ini kemungkinan disebabkan kebanyakan pasien menganggap RS Pertamina Cirebon bukan lagi satu-satunya rumah sakit dengan lingkungan fisik yang terbaik di wilayah Cirebon.

\section{Proses}

Hasil penelitian mengenai gambaran persepsi pasien terhadap bauran pemasaran proses diketahui bahwa sebagian besar persepsi pasien temasuk kedalam kelompok kurang baik yaitu sebanyak 66 orang $(66 \%)$ dan sisanya masuk kedalam kelompok nilai baik sebanyak 34 orang (34\%). Adapun komponen yang dinilai dalam penelitian ini yaitu mencakup prosedur/alur dan ketepatan waktu pelayanan di rumah sakit, serta pengaruhnya terhadap keputusan untuk memilih pelayanan rawat inap di RS Pertamina Cirebon.

Berdasarkan hasil uji chi square disimpulkan bahwa ada hubungan atau pengaruh yang signifikan antara persepsi pasien terhadap bauran pemasaran proses dengan keputusan untuk memilih pelayanan rawat inap di RS Pertamina Cirebon $(P$ value $0,005<0,05)$. Hasil uji ini memperkuat teori mengenai perilaku konsumen yang dikemukakan oleh Kotler dan Keller yang menyatakan proses keputusan pembelian dipengaruhi oleh rangsangan pemasaran yang salah satunya merupakan faktor proses. ${ }^{10}$ Hasil tersebut juga sesuai dengan penelitian yang dilakukan sebelumnya oleh RR. Nurmala Safitri, tentang faktor-faktor yang berhubungan dengan niat untuk memilih pelayanan rawat inap di RS Bogor Medical Center tahun 2011.

Hal tersebut kemungkinan disebabkan kebanyakan masyarakat memang masih menganggap prosedur pelayanan kesehatan masih merupakan hal sulit, dimana kondisi seseorang yang sedang sakit harus melalui beberapa prosedur untuk bisa mendapatkan pelayanan kesehatan sesuai yang mereka butuhkan. 


\section{Keputusan Untuk Memilih Pelayanan Rawat Inap di RS Pertamina Cirebon.}

Berdasarkan penelitian yang dilakukan dengan menyebarkan kuesioner kepada pasien rawat inap di RS Pertamina Cirebon diketahui bahwa sebagian besar pasien temasuk kedalam kelompok memilih yaitu sebanyak 72 orang (72\%). Hal ini berarti sebagian besar pasien akan memilih pelayanan rawat inap di RS Pertamina Cirebon jika suatu hari mereka memerlukan rawat inap lagi. Kemudian selebihnya masuk kedalam kelompok nilai kurang baik sebanyak 48 orang (48\%), yang artinya pasien tersebut tidak akan memilih RS Pertamina Cirebon jika suatu saat mereka perlu rawat inap lagi. Hasil penelitian ini kemungkinan disebabkan masih tingginya tingkat kepercayaan masyarakat/pasien terhadap pelayanan kesehatan di RS Pertamina, masih banyak yang menganggap RS Pertamina Cirebon sebagai leader pelayanan kesehatan di wilayah Cirebon.

Penelitian ini menggunakan teori mengenai perilaku konsumen yang dikemukakan oleh Kotler dan Keller yang menyatakan terdapat faktor-faktor yang mempengaruhi proses keputusan pembelian yang dialami konsumen dalam proses pengambilan keputusan pembelian tersebut. ${ }^{11}$

\section{SIMPULAN}

\section{Karakteristik pasien rawat inap RS Pertamina Cirebon}

Faktor personal pendidikan pasien sebagian besar termasuk kedalam tingkat pendidikan tinggi, keadaan ekonomi pasien sebagian besar tinggi, dan cara pembayaran pasien sebagian besar dengan jaminan perusahaan atau asuransi. Faktor sosial, sebagian besar pasien termasuk kedalam kelompok yang mendapat pengaruh keluarga dengan nilai kecil dan pengaruh kelompok acuan memiliki nilai sama rata atau sama banyak. Sedangkan dari faktor budaya, sebagian besar pasien termasuk ke dalam kelompok yang mendapat pengaruh budaya dengan nilai yang besar.

\section{Psikologi pasien rawat inap RS Pertamina Cirebon}

Dilihat dari faktor motivasi, sebagian besar pasien termasuk kedalam kelompok yang memiliki motivasi dengan nilai yang kecil. Faktor pembelajaran, sebagian besar pasien termasuk ke dalam kelompok yang memiliki pembelajaran dengan nilai besar. Faktor persepsi terhadap bauran pemasaran jasa sebagian besar pasien termasuk kedalam kelompok yang memiliki persepsi baik terhadap produk dan tempat, sedangkan terhadap harga, promosi, SDM, Bukti fisik, dan proses sebagian besar pasien memiliki persepsi kurang baik.

\section{Keputusan pasien untuk memilih pelayanan rawat inap di RS Pertamina Cirebon.}

Sebagian besar pasien memiliki keputusan untuk memilih pelayanan rawat inap di RS Pertamina Cirebon jika suatu hari mereka memerlukan rawat inap lagi.

\section{Hubungan karakteristik pasien dengan keputusan untuk memilih pelayanan rawat inap}

Faktor karakteristik pasien yang memiliki hubungan dengan keputusan pasien untuk memilih pelayanan rawat inap hanya karakteristik sosial pengaruh kelompok acuan, sedangkan faktor karakteristik pasien (pendidikan, pekerjaan, keadaan ekonomi, dan cara pembayaran), faktor sosial keluarga, faktor budaya tidak ada hubungan dengan keputusan untuk memilih pelayanan rawat inap di RS Pertamina Cirebon.

\section{Hubungan psikologi pasien dengan keputusan untuk memilih pelayanan rawat inap}

Faktor psikologi pasien yang memiliki hubungan dengan keputusan untuk memilih pelayanan rawat inap hanya persepsi terhadap bauran pemasaran SDM dan proses, sedangkan 
faktor lainnya seperti motivasi, pembelajaran, bauran Produk, harga, tempat, promosi, dan bukti fisik tidak ada hubungan dengan keputusan untuk memilih pelayanan rawat inap di RS Pertamina Cirebon.

\section{SARAN}

Berdasarkan hasil penelitian disarankan kepada:

1. Direktur Rumah Sakit senantiasa melakukan evaluasi kualitas pelayanan secara berkala untuk mendukung visi dan misi rumah sakit, menerapkan pemasaran yang berorientasi kepada pelanggan (customer oriented) yang dilakukan oleh seluruh bagian unit di rumah sakit

2. Kepala Manajemen Bisnis menggunakan hasil penelitian ini yang berupa gambaran variabel independen, variabel dependen, maupun hubungan antar keduanya sebagai salah satu bahan bahan pertimbangan dalam pembuatan strategi pemasaran, mensosialisasikan hasil penelitian ini maupun hasil evaluasi pelayanan lain kepada setiap unit terkait, mengkoordinasikan kegiatan survey kepuasan pelanggan secara berkala tidak hanya di unit rawat inap saja tetapi juga di unit lainnya, menginformasikan hasil survey tersebut sebagai salah satu cara mengukur kinerja dan memperbaiki mutu pelayanan.

3. Bagi Staf Humas dan Marketing untuk menerapkan pemasaran yang berorientasi pada pelanggan (customer oriented), menangani komplain pasien dengan baik serta memberikan feedback atas penyelesaian komplain tersebut dan melakukan survey kepuasan pelanggan secara lebih baik dan merata terhadap semua pasien tanpa terkecuali, agar diketahui penilaian terhadap pelayanan dari berbagai macam jenis maupun kelas.

4. Bagi Seluruh Pegawai Rumah Sakit senantiasa menerapkan pelaksanaan pelayanan profesional yang berorientasi pada pelanggan (customer oriented) sesuai dengan jenis pelayanannya masing-masing dan menciptakan komunikasi internal yang baik antar pegawai.

5. Bagi Pasien Rumah Sakit senantiasa memberikan masukan dan kritik terhadap pelayanan rumah sakit, melalui kuesioner dan kotak saran yang disediakan pihak humas RS Pertamina, agar dapat dilakukan perbaikan dan peningkatan kualitas pelayanan kesehatan yang akan diterima pasien, agar mengungkapkan setiap ketidakpuasan atau pengalaman negatif yang dialami atau disaksikan kepada bagian customer service.

\section{DAFTAR PUSTAKA}

1. Soekidjo Notoatmojo, Prof. Dr. Ilmu Perilaku Kesehatan. Jakarta:Rineka Cipta; 2010.

2. Widayatun, Tri, Rusmi. Ilmu Perilaku. Jakarta:Sagung Seto; 2009

3. Jabal Ghafur Sigli. Faktor-faktor yang berhubungan dengan perilaku mencari pengobatan; [diakses tanggal 26 Desember 2013]. Diunduh dari: http://syehaceh.wordpress.com.

4. Depkes RI. UU no.44 tahun 2009 tentang Rumah Sakit; [diakses tanggal 25 Nopember 2013]. Diunduh dari : http://www.depkes.go.id

5. Menteri Kesehatan RI. KMK no.29 tahun 2008; [diakses tanggal 25 Nopember 2013]. Diunduh dari: http://www.litbang.depkes.go.id

6. Unit Manajemen Bisnis RSPC. Laporan kepuasan pelanggan RS Pertamina Cirebon. Cirebon: Rumah Sakit Pertamina Cirebon; 2013

7. Unit Rekam Medis RSPC. Laporan Utilisasi rawat inap. Cirebon: Rumah Sakit Pertamina Cirebon; 2013 
8. Rr. Nurmalia Safitri. Faktor-faktor yang berhubungan dengan niat untuk memilih pelayanan rawat inap di Rumah Sakit Bogor Medical Center tahun 2011. Skripsi. Depok: Fakultas Kesehatan Masyarakat Universitas Indonesia; 2012

9. Riyanto,Agus, SKM, M.Kes. Aplikasi Metodologi Penelitian Kesehatan. Yogyakarta: Nuha Medika; 2011

10. Hurriyati, R. Bauran Pemasaran dan Loyalitas Konsumen. Bandung: Alfabeta; 2010

11. Wirawan, Sarlito. Psikologi Sosial (Psikologi Kelompok dan Psikologi Terapan). Jakarta: Balai Pustaka; 2005

12. Kotler, Philip \& Armstrong, Gary. Prinsip-prinsip Pemasaran. Edisi Keduabelas. Jakarta: Erlangga; 2006.

13. Schiffman \& Kanuk. Perilaku Konsumen.edisi 7. Jakarta: Prentice Hall; 2004

14. Susi Susilowati. Bauran Pemasaran. [diakses tanggal 26 Desember 2013]. Diunduh dari: http://sushety.blogspot.com/2013/12/bauran-pemasaran-marketing-mix.html 